\title{
Orthogonal Approach to Construct Cell-Like Vesicles via Pillar[5]arene-Based Amphiphilic Supramolecular Polymers
}

Leilei Rui, ${ }^{\dagger}$ Lichao Liu, ${ }^{\dagger}$ Yong Wang, ${ }^{\ddagger}$ Yun Gao, ${ }^{\dagger}$ and Weian Zhang ${ }^{*}, \uparrow$

${ }^{\dagger}$ Shanghai Key Laboratory of Functional Materials Chemistry, East China University of Science and Technology, 130 Meilong Road, Shanghai 200237, China

${ }^{\sharp}$ State Key Laboratory of Materials-Oriented Chemical Engineering, College of Chemistry and Chemical Engineering, Nanjing Tech University, Nanjing 210009, China

*Tel.: +862164253033. Fax: +862164253033.

E-mail: wazhang@ecust.edu.cn (W. Zhang). 


\section{Materials and Methods}

\subsection{Materials.}

Styrene (Shanghai Lingfeng Chemical Reagent Co.) was washed with ultrapure water until neutralization after washing with sodium hydroxide solution (5 wt \%) three times. After drying with anhydrous magnesium sulphate overnight, styrene was distilled under reduced pressure. 2, 2'-Azoisobutyronitrile (AIBN) was recrystallized from ethanol. Tetrahydrofuran (THF) was refluxed to remove water over sodium. Dimethyl formamide (DMF), toluene, dichloromethane (DCM), dichloroethane and triethylamine (TEA) were dried over calcium hydride and distilled before use. RAFT agent $S$-1-dodecyl- $S^{\prime}$-(R, $R^{\prime}$-dimethyl- $R^{\prime \prime}$-acetic acid) trithiocarbonate (DDAT) was synthesized according to the previous literature procedure. ${ }^{1}$ Methoxy poly(ethylene glycol) (PEG, $M_{\mathrm{n}}=2$ 000), 4-methoxyphenol, $p$-hydroxyl anisole, paraformaldehyde $\left(\mathrm{CH}_{2} \mathrm{O}\right)_{\mathrm{n}}$, 2-bromoethanol, acetyl chloride, succinic anhydride and 4, 4'-bipyridine were all purchased from Aladdin Reagents of China and used directly as received. Other common reagents and solvents were purchased from Sinopharm Chemical Reagent Co. Ltd (SRC) and purified by standard procedure.

\subsection{Methods}

${ }^{1} \mathrm{H}$ NMR spectra and 2D NOESY spectrum were recorded at $400 \mathrm{MHz}$, using a BRUKER AV400 Spectrophotometer, in $\mathrm{CDCl}_{3}$ with tetramethylsilane (TMS) as an internal reference. Absorption spectra were determined on a SHIMADZU UV-2550 UV spectrophotometer using in quartz Cuvette with $1 \mathrm{~cm}$ beam path length, and fluorescence spectra measurements were performed on a Varian's Cary Eclipse fluorescence spectrophotometer at room temperature with excitation and emission slit width of $10 \mathrm{~nm}$ and $5 \mathrm{~nm}$, respectively. Dynamic light scattering (DLS) and zeta potential measurements were carried out with a BECKMAN COULTER Delasa Nano C particle analyzer. All the measurements were carried out at room temperature. Transmission electron microscopy (TEM) analysis was performed on a JEOL JEM1400 electron microscope operated at $100 \mathrm{kV}$. Samples for TEM were prepared 
by dropping the micelle solution onto a carbon-coated copper grid and then dried at room temperature. The molecular weight was measured by MALDI-TOF-mass spectra (Micromass GCTTM) with THF as solvent.

\section{Syntheses of compounds and Characterizations}

Scheme S1. Synthesis of poly(ethylene glycol)-pillar[5]arene (PEG-P[5]A).
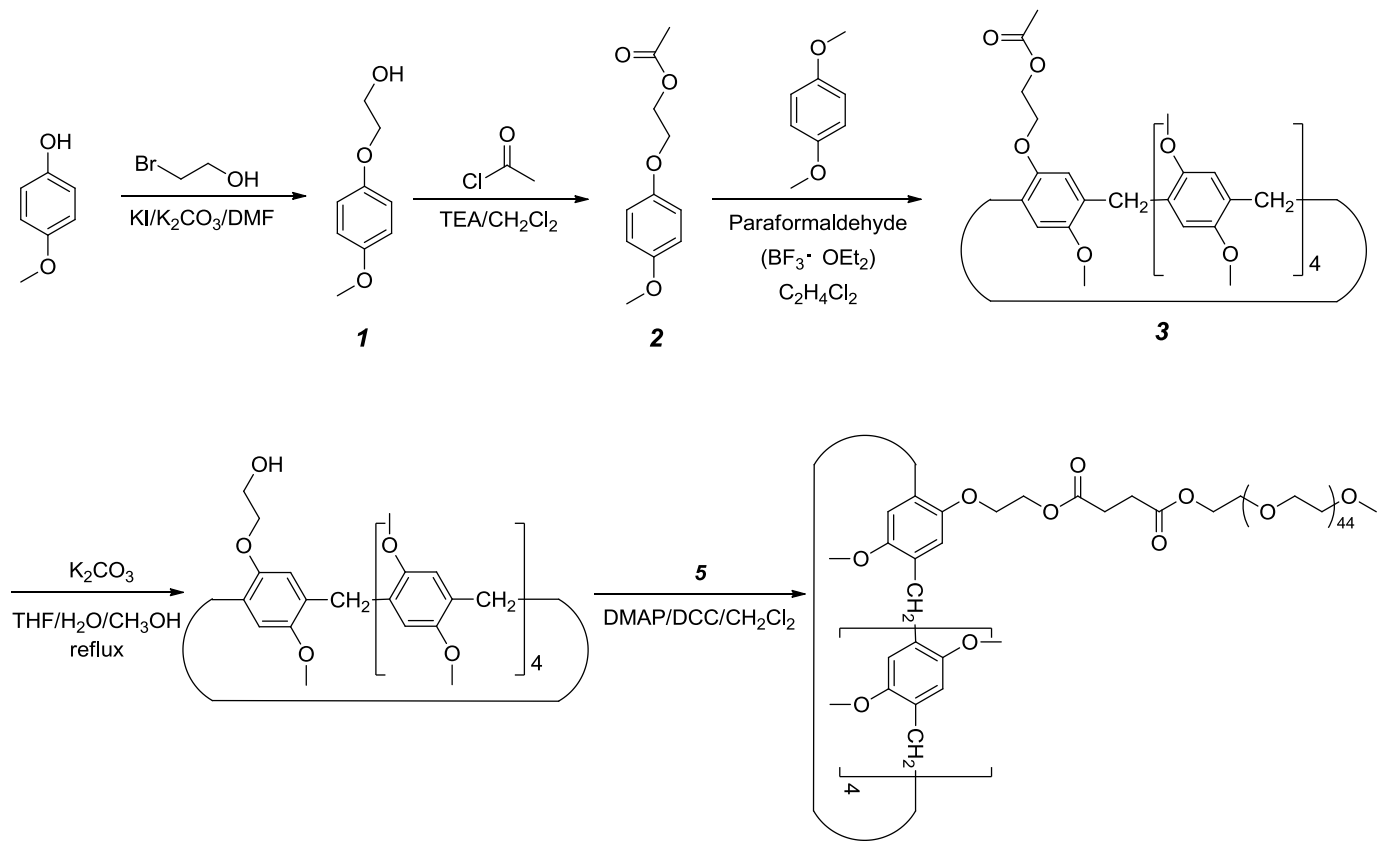

PEG-P[5]A

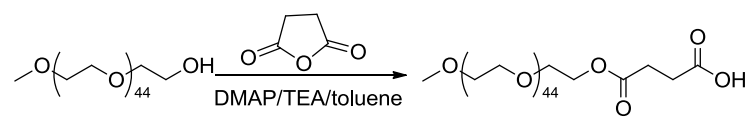

5

Scheme S2. Synthesis of styrene-methyl viologen (PS-EV).

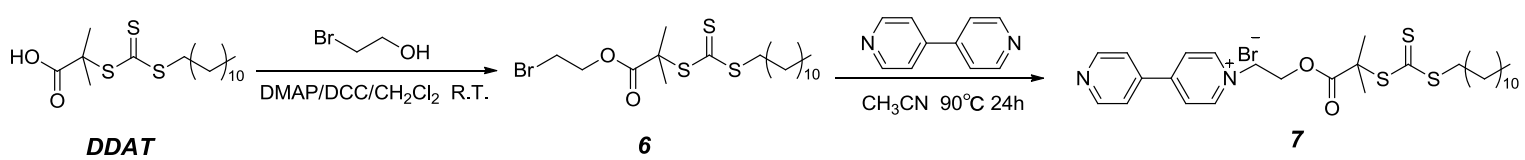

DDAT

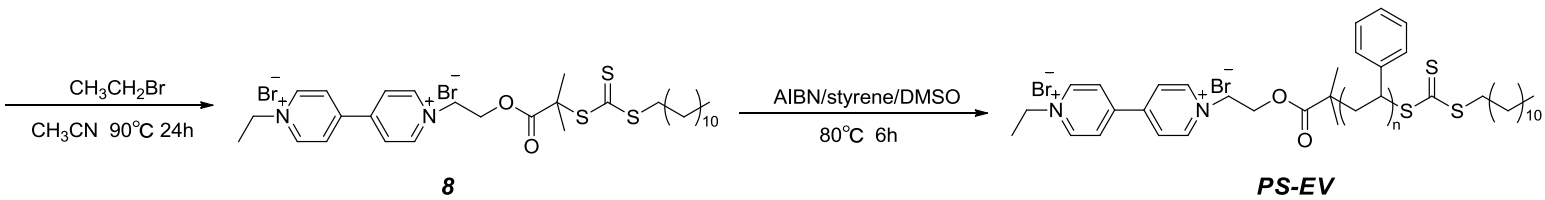




\section{Synthesis of 2-(4-methoxyphenoxy)ethanol 1.}

4-Methoxyphenol (2.48 g, $20 \mathrm{mmol})$ and potassium carbonate (11.06 g, $80 \mathrm{mmol})$ were dissolved in DMF. After purging with nitrogen for $30 \mathrm{~min}$ to eliminate the oxygen, 2-bromoethanol (2.83 mL, $20 \mathrm{mmol})$ in $15 \mathrm{~mL}$ of DMF was added dropwise. The reaction mixture was stirred at $70{ }^{\circ} \mathrm{C}$ for $24 \mathrm{~h}$ and was evaporated. The obtained solid was dissolved in $100 \mathrm{~mL}$ of ethyl acetate. After extraction with an aqueous solution of saturated sodium chloride $(\mathrm{NaCl})$, the organic phase was dried over anhydrous magnesium sulfate $\left(\mathrm{MgSO}_{4}\right)$. After filtration, the filtrate was concentrated and further purified by silica gel column chromatography using petroleum ether-ethyl acetate $(5: 1 \mathrm{v} / \mathrm{v})$ as the eluent. After removing the solvents by a rotary evaporator, the final product was obtained as a light yellow solid (0.88 g, yield: $17.7 \%)$. ${ }^{1} \mathrm{H}$ NMR $\left(400 \mathrm{MHz}, \mathrm{CDCl}_{3}, \delta\right): 3.77\left(\mathrm{~s}, 3 \mathrm{H},-\mathrm{OCH}_{3}\right), 3.93\left(\mathrm{t}, 2 \mathrm{H},-\mathrm{OCH}_{2^{-}}\right), 4.03(\mathrm{t}, 2 \mathrm{H}$, $\left.-\mathrm{CH}_{2} \mathrm{OH}\right), 6.85(\mathrm{~m}, 4 \mathrm{H}, \mathrm{ArH})$.

\section{Synthesis of 2-(4-methoxyphenoxy)ethyl acetate 2.}

Compound 1 (0.82 g, $4.88 \mathrm{mmol})$ and anhydrous triethylamine $(0.8 \mathrm{~mL}, 5.74 \mathrm{mmol})$ were dissolved in anhydrous dichloromethane $(3 \mathrm{~mL})$. Acetyl chloride $(0.53 \mathrm{~mL}, 7.49$ mmol) in $2 \mathrm{~mL}$ anhydrous dichloromethane was added dropwise. The reaction mixture was stirred at room temperature for $24 \mathrm{~h}$. After filtration, the filtrate was poured into $50 \mathrm{~mL}$ dichloromethane, washed with saturated sodium bicarbonate and dried over anhydrous $\mathrm{MgSO}_{4}$. The solvent was concentrated and further purified by silica gel column chromatography using ethyl acetate-petroleum ether (1:10, v/v). After drying two days in a vacuum oven at room temperature, a light yellow solid 2 was obtained (0.75 g, yield: 73.1\%). ${ }^{1} \mathrm{H}$ NMR (400 $\left.\mathrm{MHz}, \mathrm{CDCl}_{3}, \delta\right): 2.03$ (s, 3H, $\left.-\mathrm{OOCCH}_{3}\right), 3.70\left(\mathrm{t}, 3 \mathrm{H},-\mathrm{OCH}_{3}\right), 4.05\left(\mathrm{t}, 2 \mathrm{H},-\mathrm{CH}_{2} \mathrm{OOCCH}_{3}\right), 4.33\left(\mathrm{t}, 2 \mathrm{H},-\mathrm{CH}_{2} \mathrm{OAr}-\right)$, $6.78(\mathrm{~m}, 4 \mathrm{H}, \mathrm{ArH})$.

\section{Synthesis of the monofunctional pillar[5]arenes 3.}

Similar procedure was performed according to the previous literature. Compound 2 $(0.26 \mathrm{~g}, 1.25 \mathrm{mmol})$ and 1, 4-dimethoxybenzene $(1.38 \mathrm{~g}, 10.00 \mathrm{mmol})$ were dissolved 
in dry dichloromethane $(50 \mathrm{~mL})$. After purging with nitrogen for $30 \mathrm{~min}$ to eliminate the oxygen, paraformaldehyde $(0.93 \mathrm{~g}, 30 \mathrm{mmol})$ was introduced under nitrogen. After stirring for $30 \mathrm{~min}$ at room temperature, boron trifluoride etherate $(1.25 \mathrm{~mL}, 10$ mmol) was added. The reaction mixture was stirred for $3 \mathrm{~h}$ at room temperature under nitrogen atmosphere, and then precipitated into an excess of methanol. After filtration, the filter cake was dissolved in $10 \mathrm{~mL} \mathrm{CH}_{2} \mathrm{Cl}_{2}$ and purified silica gel column chromatography using petroleum ether-ethyl acetate $(5: 1 \mathrm{v} / \mathrm{v})$ as the eluent to give 3 (0.23 g, yield: $24.1 \%$ ). ${ }^{1} \mathrm{H}$ NMR (400 MHz, $\mathrm{CDCl}_{3}, \delta$ ): 1.98 (s, 3H, $-\mathrm{OOCCH}_{3}$ ), 3.65 $\left(\mathrm{s}, 3 \mathrm{H},-\mathrm{ArOCH}_{3}\right), 3.70$ (s, 24H, $\left.-\mathrm{ArOCH}_{3}\right), 3.80$ (s, 10H, - $\left.\mathrm{ArCH} \mathrm{H}_{2} \mathrm{Ar}-\right), 4.03$ (t, 2H, $\left.-\mathrm{CH}_{2} \mathrm{OOCCH}_{3}\right), 4.40$ (t, 2H, $\left.-\mathrm{CH}_{2} \mathrm{OAr}-\right), 6.82-6.77$ (m, 10H, $\mathrm{ArH}$ ).

\section{Synthesis of 4 .}

Compound 3 (158 mg, $0.18 \mathrm{mmol})$ and potassium carbonate $(203 \mathrm{mg}, 0.73 \mathrm{mmol})$ were charged into a round flask equipped with a magnetic stirring bar. THF (15 mL), pure water $(15 \mathrm{~mL})$, and methanol $(15 \mathrm{~mL})$ were poured into the round flask and refluxed overnight at $90{ }^{\circ} \mathrm{C}$. The reaction mixture was dissolved in $100 \mathrm{~mL}$ of $\mathrm{CH}_{2} \mathrm{Cl}_{2}$. After extraction with an aqueous solution of saturated sodium chloride $(\mathrm{NaCl})$, the organic phase was dried over anhydrous magnesium sulfate $\left(\mathrm{MgSO}_{4}\right)$. After filtration, the filtrate was concentrated and further purified by silica gel column chromatography using dichloromethane-petroleum ether $(5: 1, \mathrm{v} / \mathrm{v})$. After drying two days in a vacuum oven at room temperature, a white solid 4 was obtained (132 mg, yield: $92.7 \%) .{ }^{1} \mathrm{H}$ NMR (400 MHz, $\left.\mathrm{CDCl}_{3}, \delta\right): 3.76-3.69$ (m, 27H, $\left.-\mathrm{ArOCH}_{3}\right), 3.82$ (s, 10H, - $\mathrm{ArCH}_{2} \mathrm{Ar}-$ ), $3.87\left(\mathrm{t}, 2 \mathrm{H},-\mathrm{CH}_{2} \mathrm{OH}\right), 4.44\left(\mathrm{t}, 2 \mathrm{H},-\mathrm{CH}_{2} \mathrm{OAr}-\right), 6.85-6.72(\mathrm{~m}, 10 \mathrm{H}, \mathrm{ArH})$.

\section{Synthesis of 5 .}

A typical procedure was followed the previous literature. ${ }^{2}$ A white solid was obtained (3.66 g, yield: 82\%). ${ }^{1} \mathrm{H}$ NMR (400 MHz, $\left.\mathrm{CDCl}_{3}, \delta\right): 2.63$ (m, 4H, - $\left.\mathrm{OOCCH}_{2} \mathrm{CH}_{2} \mathrm{COOH}\right), 3.38$ (s, 3H, $\mathrm{CH}_{3} \mathrm{O}-$ ), 3.67-3.46 (m, - $\mathrm{OCH}_{2} \mathrm{CH}_{2} \mathrm{O}-$ ), 4.26 (t, $2 \mathrm{H}$, $-\mathrm{CH}_{2} \mathrm{OOC}-$ ). 


\section{Synthesis of $P E G-P[5] A$.}

Compound 4 (40 mg, $0.052 \mathrm{mmol}$ ), DMAP (1.6 mg, $0.013 \mathrm{mmol}$ ), and compound 5 (103 mg, $0.052 \mathrm{mmol}, M_{\mathrm{n}}=2000 \mathrm{~g} / \mathrm{mol}$ ) were dissolved in anhydrous dichloromethane $(10 \mathrm{~mL})$. The flask was cooled to $0{ }^{\circ} \mathrm{C}$ in ice-water bath. Then DCC (106 mg, $0.52 \mathrm{mmol}$ ) in $4 \mathrm{~mL}$ of anhydrous dichloromethane was added dropwise and stirred for $24 \mathrm{~h}$ at room temperature. After filtration, the filtrate was concentrated and precipitated into cold diethyl ether three times. PEG-P[5]A was obtained as a white solid after drying at room temperature in a vacuum oven 48 h. $(80 \mathrm{mg}$, yield: $56 \%) .{ }^{1} \mathrm{H}$ NMR (400 MHz, $\left.\mathrm{CDCl}_{3}, \delta\right): 2.66\left(\mathrm{~m}, 4 \mathrm{H},-\mathrm{OOCCH}_{2} \mathrm{CH}_{2} \mathrm{COOH}\right), 3.38$ (s, 3H, $\left.\mathrm{CH}_{3} \mathrm{O}-\right)$, 3.71-3.47 (m, - $\left.\mathrm{OCH}_{2} \mathrm{CH}_{2} \mathrm{O}-,-\mathrm{ArOCH}_{3}\right), 3.77$ (s, $\left.10 \mathrm{H},-\mathrm{ArCH}_{2} \mathrm{Ar}-\right), 4.00$ (m, $\left.2 \mathrm{H},-\mathrm{ArOCH} 2 \mathrm{CH}_{2} \mathrm{OOC}-\right), 4.22\left(\mathrm{~m}, 2 \mathrm{H},-\mathrm{CH}_{2} \mathrm{OOC}-\right), 4.41\left(\mathrm{~m}, 2 \mathrm{H},-\mathrm{CH}_{2} \mathrm{OAr}-\right)$, 6.79-6.75 (m, 10H, ArH).

\section{Synthesis of 6 .}

DDAT (915.6 mg, $2.50 \mathrm{mmol}$ ), DMAP (37 mg, $0.30 \mathrm{mmol}$ ), and 2-bromoethanol $(0.23 \mathrm{~mL}, 3.13 \mathrm{mmol})$ were dissolved in anhydrous dichloromethane $(25 \mathrm{~mL})$. The flask was cooled to $0{ }^{\circ} \mathrm{C}$ in ice-water bath. Then DCC (670 mg, $\left.6.5 \mathrm{mmol}\right)$ in $10 \mathrm{~mL}$ of anhydrous dichloromethane was added dropwise and stirred for $24 \mathrm{~h}$ at room temperature. After filtration, the filtrate was concentrated and further purified by silica gel column chromatography using dichloromethane-petroleum ether $(2: 1, \mathrm{v} / \mathrm{v})$. After drying two days in a vacuum oven at room temperature, a yellow syrupy liquid 6 was obtained (1.12 g, yield: 91.7\%). ${ }^{1} \mathrm{H} \mathrm{NMR}\left(400 \mathrm{MHz}, \mathrm{CDCl}_{3}, \delta\right.$ ): 0.90 (t, 3H, $\left.-\mathrm{CH}_{2} \mathrm{CH} 3\right), 1.45-1.27\left(\mathrm{~m}, 18 \mathrm{H},-\mathrm{CH}_{2}\left(\mathrm{CH}_{2}\right)_{9} \mathrm{CH}_{3}\right), 1.68$ (m, $\left.2 \mathrm{H},-\mathrm{SC}(=\mathrm{S}) \mathrm{SCH}_{2} \mathrm{CH}_{2^{-}}\right)$, $1.73\left(\mathrm{~s}, \quad 6 \mathrm{H},-\mathrm{C}\left(\mathrm{CH}_{3}\right)_{2} \mathrm{SC}(=\mathrm{S}) \mathrm{S}-\right), 3.29\left(\mathrm{t}, \quad 2 \mathrm{H}, \quad-\mathrm{SC}(=\mathrm{S}) \mathrm{SCH}_{2^{-}}\right), 3.52 \quad(\mathrm{t}, \quad 2 \mathrm{H}$, $\mathrm{BrCH}_{2} \mathrm{CH}_{2-}$ ), 4.42 (t, $2 \mathrm{H}, \mathrm{BrCH}_{2} \mathrm{CH}_{2} \mathrm{OOC}-$ ).

\section{Synthesis of 7 .}

Compound 6 (471 mg, $1.00 \mathrm{mmol}$ ) and 4, 4-bipyridine (469 mg, $4.00 \mathrm{mmol}$ ) were dissolved in acetonitrile $(10 \mathrm{~mL})$ and refluxed at $90{ }^{\circ} \mathrm{C}$ for $24 \mathrm{~h}$. After cooling, the yellow precipitate was filtered and suspended in $40 \mathrm{~mL}$ of hot DMF. The cooled 
solution was precipitated into the cold diethyl ether to obtain the white/pale yellow solid. The filter cake was washed three times with ethyl acetate, and dried in a vacuum oven overnight at room temperature (0.35 g, yield: $59.7 \%) .{ }^{1} \mathrm{H}$ NMR (400 $\left.\mathrm{MHz}, \mathrm{CDCl}_{3}, \delta\right): 0.88\left(\mathrm{t}, 3 \mathrm{H},-\mathrm{CH}_{2} \mathrm{CH}_{3}\right), 1.30-1.20\left(\mathrm{~m}, 18 \mathrm{H},-\mathrm{CH}_{2}\left(\mathrm{CH}_{2}\right)_{9} \mathrm{CH}_{3}\right), 1.43$ $\left(\mathrm{m}, 2 \mathrm{H},-\mathrm{SC}(=\mathrm{S}) \mathrm{SCH}_{2} \mathrm{CH}_{2^{-}}\right), 1.66\left(\mathrm{~s}, 6 \mathrm{H},-\mathrm{C}\left(\mathrm{CH}_{3}\right)_{2} \mathrm{SC}(=\mathrm{S}) \mathrm{S}-\right), 2.93 \quad(\mathrm{~m}, 2 \mathrm{H}$, $\left.-\mathrm{SC}(=\mathrm{S}) \mathrm{SCH}_{2-}\right), 4.68\left(\mathrm{t}, 2 \mathrm{H},-\mathrm{NCH}_{2} \mathrm{CH}_{2^{-}}\right), 5.54$ (t, 2H, $\left.\mathrm{NCH}_{2} \mathrm{CH}_{2} \mathrm{OOC}-\right)$ ), $7.71(\mathrm{~d}, 2 \mathrm{H}$, MV aryl-H ), 8.24 (d, 2H, MV aryl-H ), 8.91 (d, 2H, MV aryl-H ), 9.56 (d, 2H, MV aryl-H).

\section{Synthesis of 8 .}

Compound 7 (240 mg, $0.38 \mathrm{mmol})$ and bromoethane (417 mg, $3.83 \mathrm{mmol})$ were dissolved in $10 \mathrm{~mL}$ acetonitrile. The mixture reaction was refluxed at $90{ }^{\circ} \mathrm{C}$ for $24 \mathrm{~h}$ and then the bromoethane and acetonitrile were removed under reduced pressure. The remaining solid was added $10 \mathrm{~mL}$ of $\mathrm{DMF}$ and was precipitated into large amount of ethyl acetate to obtain the yellowish solid. After filtration, the filter cake was washed three times with acetonitrile and dried in a vacuum oven overnight at room

temperature to provide 8 (265 mg, yield: $94.1 \%)$. ${ }^{1} \mathrm{H}$ NMR (400 MHz, DMSO, $\delta$ ): $0.86\left(\mathrm{~m}, 3 \mathrm{H},-\mathrm{CH}_{2} \mathrm{CH}_{3}\right), 1.27-1.07\left(\mathrm{~m}, 18 \mathrm{H},-\mathrm{CH}_{2}\left(\mathrm{CH}_{2}\right)_{9} \mathrm{CH}_{3}\right), 1.40(\mathrm{~m}, 2 \mathrm{H}$, $\left.-\mathrm{SC}(=\mathrm{S}) \mathrm{SCH}_{2} \mathrm{CH}_{2^{-}}\right), \quad 1.59\left(\mathrm{~s}, \quad 9 \mathrm{H},-\mathrm{C}\left(\mathrm{CH}_{3}\right)_{2} \mathrm{SC}(=\mathrm{S}) \mathrm{S}-,-\mathrm{CH}_{2} \mathrm{CH}_{3}\right), 2.91 \quad(\mathrm{dt}, \quad 2 \mathrm{H}$, $\left.-\mathrm{SC}(=\mathrm{S}) \mathrm{SCH}_{2^{-}}\right), 4.57\left(\mathrm{~m}, 2 \mathrm{H},-\mathrm{NCH}_{2} \mathrm{CH}_{2}\right), 4.74\left(\mathrm{~m}, 2 \mathrm{H},-\mathrm{NCH}_{2} \mathrm{CH}_{3}\right), 5.03(\mathrm{~m}$, 2H, $\mathrm{NCH}_{2} \mathrm{CH}_{2} \mathrm{OOC}-$ ), 9.44-8.11 (MV aryl-H, 8H).

\section{Synthesis of $P S-E V$ homopolymer.}

The typical procedure for synthesis of $\boldsymbol{P S} \boldsymbol{E} \boldsymbol{V}$ via RAFT polymerization is described below: styrene (2.31 mL, $20 \mathrm{mmol})$, compound 8 (147.2 $\mathrm{mg}, 0.20 \mathrm{mmol})$, AIBN (6.57 $\mathrm{mg}, 0.04 \mathrm{mmol}$ ), and $3 \mathrm{~mL}$ DMSO were charged into a glass flask equipped with a magnetic stirring bar. The flask was degassed by three freeze-evacuate-thaw cycles and then sealed under vacuum. The polymerization was carried out in an oil bath at $80{ }^{\circ} \mathrm{C}$ for $6 \mathrm{~h}$, and then quenched into liquid nitrogen. The solution was precipitated into an excess of cold petroleum ether three times. The orange-red solid was obtained 
after drying in a vacuum oven overnight at room temperature (770 $\mathrm{mg}, \boldsymbol{P S}_{\mathbf{2}} \mathbf{- E} \boldsymbol{V}$ yield: $\left.34.4 \%, M_{\mathrm{n}}=3800, \mathrm{PD}=1.04\right)$.

\section{Investigation of the interactions between PEG-P[5]A and PS $_{29}-E V$.}

In order to investigate the stoichiometry and association constant for the complexation between PEG-P[5]A and $\mathbf{P S}_{\mathbf{2 9}} \mathbf{- E V}$, fluorescence titration experiments were conducted to estimate the association constant $\left(K_{\mathrm{a}}\right)$ of PEG-P[5]A $\mathbf{P S}_{\mathbf{2 9}} \mathbf{- E V}$ with solutions of THF, which had a constant concentration of PEG-P[5]A $\left(2.50 \times 10^{-5} \mathrm{M}\right)$ and varying concentrations of $\mathbf{P S}_{\mathbf{2 9}} \mathbf{- E V}$. By a molar ratio plot, 1:1 stoichiometry was obtained for the complexation between PEG-P[5]A and $\mathbf{P S}_{\mathbf{2 9}} \mathbf{- E V}$.

The non-linear curve-fittings were based on the following equation:

$$
\begin{aligned}
& \Delta F=\left(\Delta F_{\circ} /[\mathrm{H}]_{0}\right)\left(0.5[\mathrm{G}]_{0}+0.5\left([\mathrm{H}]_{0}+1 / K_{\mathrm{a}}\right)-\left(0 . 5 \left([\mathrm{G}]_{0}^{2}+\left(2[\mathrm{G}]_{0}\left(1 / K_{\mathrm{a}}-[\mathrm{H}]_{0}\right)\right)+\right.\right.\right. \\
& \left.\left.\left.\left(1 / K_{\mathrm{a}}+[\mathrm{H}]_{0}\right)^{2}\right)^{0.5}\right)\right)
\end{aligned}
$$

Where, $\Delta F$ is the fluorescence intensity changes at $330 \mathrm{~nm}$ at $[\mathrm{H}]_{0} ; \Delta F_{\infty}$ is the fluorescence intensity changes at $330 \mathrm{~nm}$ when PEG-P[5]A is completely complexed; $[\mathrm{H}]_{0}$ is the fixed initial concentration of PEG-P[5]A and $[\mathrm{G}]_{0}$ is the initial concentration of $\mathbf{P S}_{\mathbf{2 9}}-\mathbf{E V}$. $^{3-5}$

\section{Critical vesiculation concentration (CVC) of the supramolecular copolymer.}

The CVC of PEG-P[5]AدPS $\mathbf{P S}_{\mathbf{2 9}} \mathbf{- E V}$ was determined by a fluorescence spectrometer using pyrene as a hydrophobic probe. $5 \mu \mathrm{L}$ of $1.2 \times 10^{-3} \mathrm{M}$ pyrene in acetone was added into a series of volumetric flasks and then allowed to evaporate at room temperature. PEG-P[5]A $\mathbf{P S}_{\mathbf{2 9}}$-EV copolymer solution was diluted to a series of concentrations ranging from 0.25 to $20 \mu \mathrm{g} / \mathrm{mL}$ by ultrapure water and then sonicated $30 \mathrm{~min}$ at room temperature. The different concentrations of the copolymer was monitored by the fluorescent intensity of pyrene $(\lambda=382 \mathrm{~nm}$ and $\lambda=372 \mathrm{~nm})$ with the excitation wavelength $335 \mathrm{~nm}$. The CVC was estimated by extrapolating the 
intensity ratio $I_{382} / I_{372}$ from low to high concentrations of the copolymer. The CVC of PEG-P[5]AつPS 2 -EV supramolecular assemblies in aqueous solution is about $5.1 \times 10^{-3} \mathrm{mg} / \mathrm{mL}$.

\section{Self-assembly of the supramolecular block copolymers in aqueous solution.}

In a typical self-assembly experiment, $0.5 \mathrm{~mL}$ of PEG-P[5]A $(2.0 \mathrm{mg} / \mathrm{mL})$ in THF was charged into a screw-cap vial. The solution of $\mathbf{P S}_{\mathbf{2 9}}-\mathbf{E V}(2.0 \mathrm{mg} / \mathrm{mL})$ in THF was slowly dropped into the solution of PEG-P[5]A in equivalent molarity under vigorous stirring, and then stirred and maintained at $25{ }^{\circ} \mathrm{C}$ with a water bath for $2 \mathrm{~h}$. Subsequently, $4 \mathrm{~mL}$ of deionized water was slowly injected into the mixed solution $(1.0 \mathrm{~mL})$ of PEG-P[5]A and $\mathbf{P S}_{\mathbf{2 9}}$-EV in THF at an addition rate of $2.0 \mathrm{~mL} / \mathrm{h}$ under strong stirring at room temperature. After stirring for another $2 \mathrm{~h}$, THF was removed by dialysis (MWCO $12 \mathrm{kDa}$ ) against deionized water for 2 days (renew fresh water for 6 times). Finally, the concentration of the assembled solution was $0.3 \mathrm{mg} / \mathrm{mL}$.

\section{Self-assembly behavior of PEG-P[5]AつPS ${ }_{29}-\mathrm{EV}$ by varying the ratio of PEG-P[5]A to $\mathrm{PS}_{29}-\mathrm{EV}$.}

In previous research, the self-assembled morphologies of amphiphilic copolymers are highly dependent on polymer composition. In this work, the effect of polymer composition on the self-assembly behavior of the supramolecular copolymer was also systematically studied by varying the ratio of PEG-P[5]A to $\mathbf{P S}_{\mathbf{2 9}} \mathbf{- E V}$. Firstly, PEG-P[5]A is also an amphiphilic polymer, which has a PEG chain as a hydrophilic segment and $\mathbf{P}[\mathbf{5}] \mathbf{A}$ as a hydrophobic moiety. The TEM image revealed that amphiphilic PEG-P[5]A can self-assemble into spherical micelles with a well-defined core-shell structure composed of grey shells and black inner cores, and the size of the micelles was around $125 \mathrm{~nm}$ (Figure S21a). Moreover, we can obtained a series of self-assembled morphologies including micelles (Figure S21b), cell-like vesicles (Figure 3a), and large compound micelles (Figure S21c) by varying the molar ratio of PEG-P[5]A to $\mathbf{P S}_{\mathbf{2 9}}$-EV of 2:1, 1:1 and 1:2, respectively. Similarly to PEG-P[5]A, $\mathbf{P S}_{29}-\mathbf{E V}$ is also an amphiphilic polymer which contains a hydrophobic PS chain and a 
hydrophilic EV moiety, but its ratio of hydrophobic/hydrophilic composition is much higher than that of PEG-P[5]A. Thus, $\mathbf{P S}_{\mathbf{2 9}} \mathbf{- E V}$ clearly showed that it could self-assemble into perfect large compound micelles with a diameter ranging from 700 to $1000 \mathrm{~nm}$ (Figure S21d). Additionally, UV-vis spectroscopy also revealed the formation of the assembled aggregates of $\mathbf{P S}_{\mathbf{2 9}} \mathbf{- E V}$ in water (Figure S17), since the absorption spectrum of EV moieties had an absorption at near $310 \mathrm{~nm}$, red-shifted from $260 \mathrm{~nm} .{ }^{6}$ The DLS results in Figure S22 and Figure $3 \mathrm{c}$ showed that the average sizes of supramolecular polymer aggregates (PEG-P[5]A:PS $\mathbf{P 2}_{\mathbf{2}} \mathbf{E V}=1: 0,2: 1,1: 1,1: 2$, 0:1) were respectively $125 \mathrm{~nm}, 250 \mathrm{~nm}, 440 \mathrm{~nm}, 470 \mathrm{~nm}$ and $860 \mathrm{~nm}$, which all agreed well with the TEM results, moreover, the diameters of the self-assembled aggregates clearly increased by the increase of $\mathbf{P S}_{\mathbf{2 9}} \mathbf{- E V}$. Furthermore, $\zeta$-potential measurements were performed to examine the stability of the obtained aggregates with the different molar ratio of PEG-P[5]A to $\mathbf{P S}_{\mathbf{2 9}}$-EV (Figure S23), and it was found that the high $\zeta$-potentials existed in these aggregates, which could induce a higher stability of these aggregates due to the repulsive force between them. ${ }^{41,42}$ Therefore, the average size and morphology of the stable aggregates are highly dependent on the ratio of PEG-P[5]A to $\mathbf{P S}_{\mathbf{2 9}}$-EV.

\section{Calcein loading and release PEG-P[5]AدPS 29 -EV.}

Calcein-loaded vesicles were prepared as follows: $1.14 \mathrm{~mL}$ of $\mathbf{P S}_{\mathbf{2 9}}-\mathbf{E V}(2.0 \mathrm{mg} / \mathrm{mL})$ in THF was slowly dropped into a $0.86 \mathrm{~mL}$ of PEG-P[5]A $(2.0 \mathrm{mg} / \mathrm{mL})$ in THF in equivalent molarity under vigorous stirring and then added $1 \mathrm{mg}$ calcein into the mixed solution. After stirring and maintaining at $25^{\circ} \mathrm{C}$ with a water bath for $2 \mathrm{~h}, 8 \mathrm{~mL}$ of deionized water was slowly injected into the mixed solution at an addition rate of $2.0 \mathrm{~mL} / \mathrm{h}$ under strong stirring at room temperature. After standing for another $2 \mathrm{~h}$ in the dark, the prepared calcein-loaded vesicles were purified by dialysis in deionized water using a dialysis membrane (MWCO $12 \mathrm{kDa}$ ) for several times in the dark until the water outside the dialysis bag showed negligible calcein fluorescence.

The redox typical release experiment was further performed as following: a certain amount of $\mathrm{Na}_{2} \mathrm{~S}_{2} \mathrm{O}_{3}$ solution was added into $6 \mathrm{~mL}$ of calcein-loaded vesicular solution, 
the final concentration was $0.5 \mathrm{mg} / \mathrm{mL}$ in the vesicular solution. At predetermined time intervals, $2 \mathrm{~mL}$ of the release media was taken out for measuring the released calcein fluorescence intensity by the fluorescence technique, and then it was returned to the original release media after measuring. The fluorescence intensity of calcein was determined by measuring emission intensity at $525 \mathrm{~nm}$. A nearly $100 \%$ release of calcein from calcein-loaded vesicles could be obtained by adding Triton X-100 to the vesicular solution.

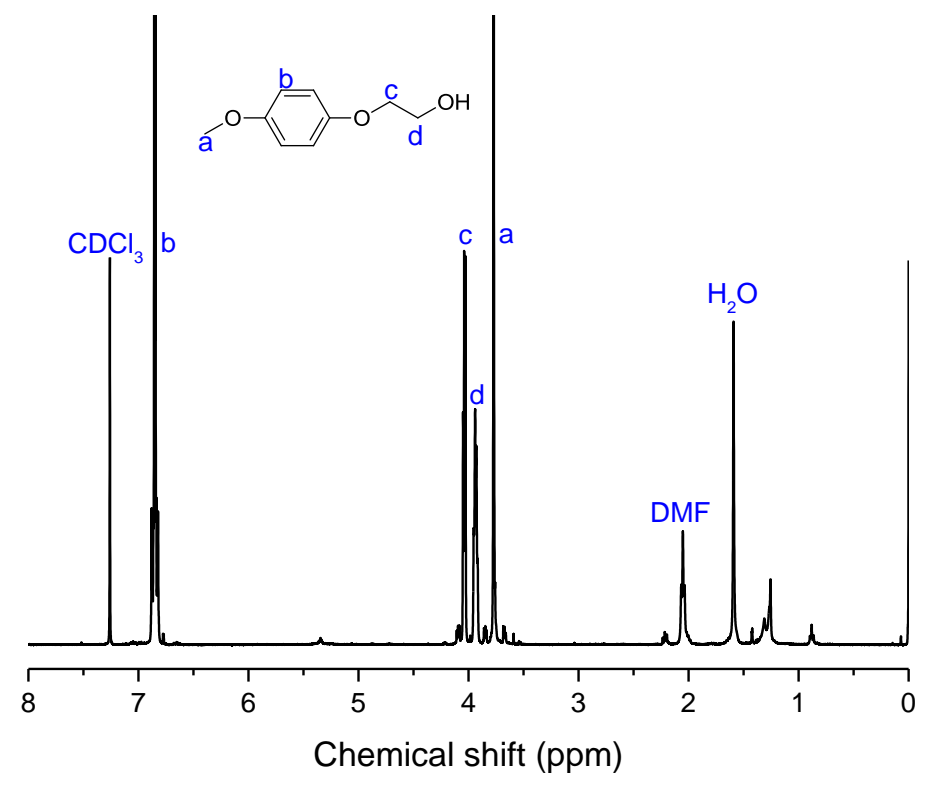

Figure S1. ${ }^{1} \mathrm{H}$ NMR spectrum of 2-(4-methoxyphenoxy)ethanol 1. 


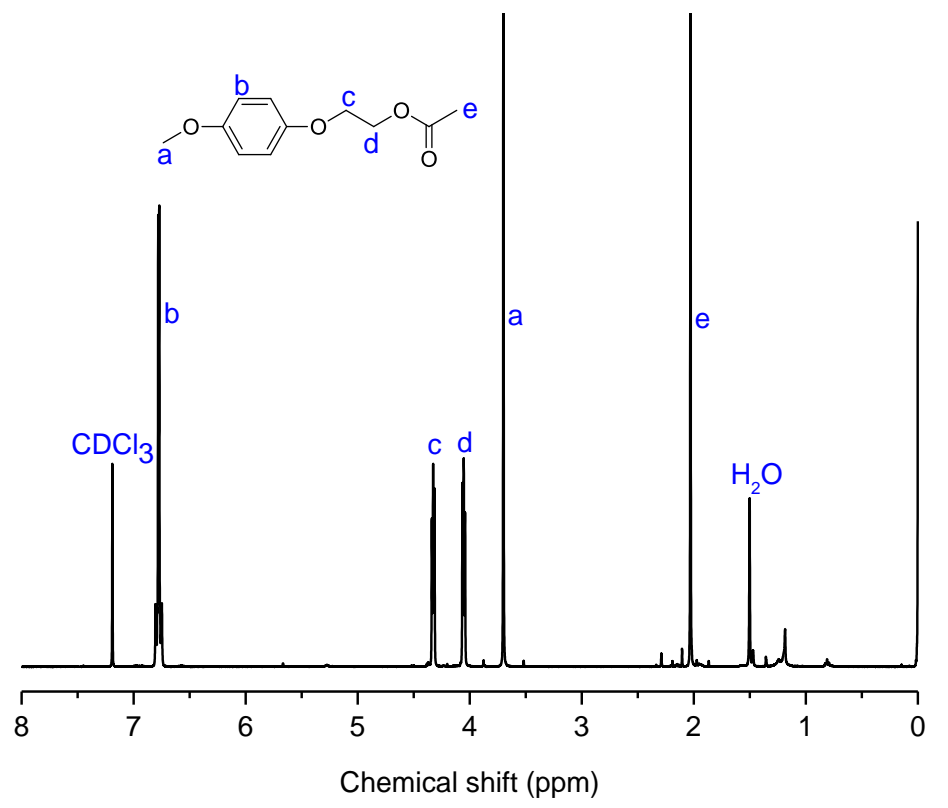

Figure S2. ${ }^{1} \mathrm{H}$ NMR spectrum of 2-(4-methoxyphenoxy)ethyl acetate 2.

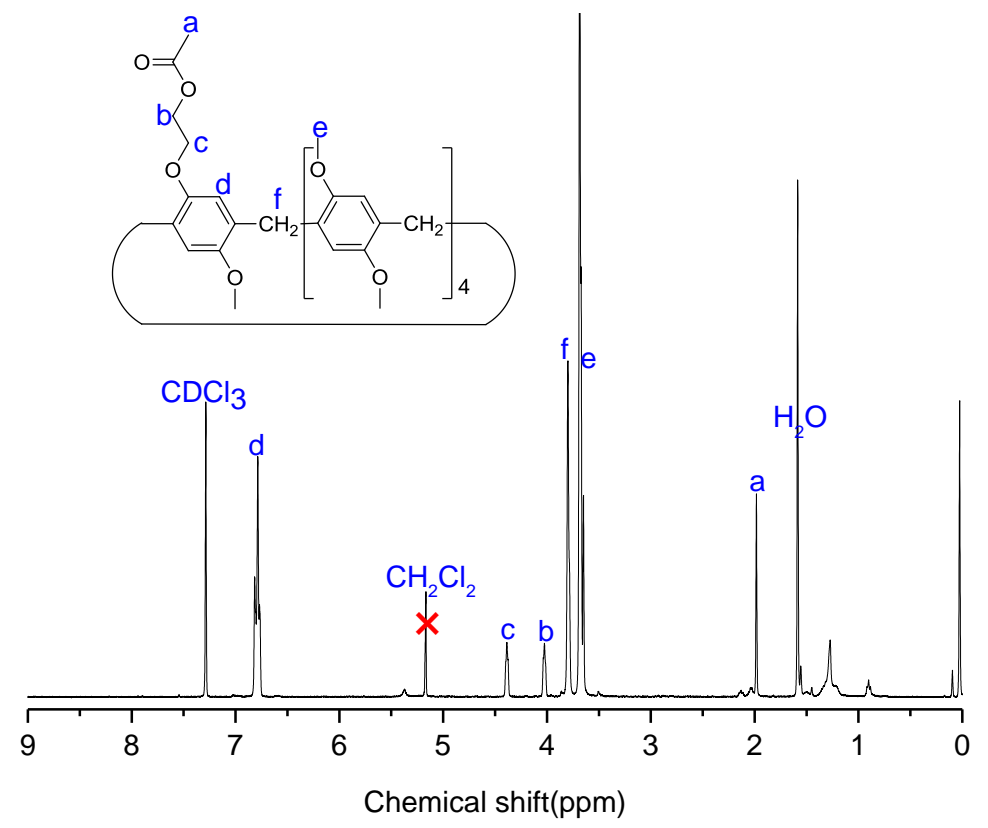

Figure S3. ${ }^{1} \mathrm{H}$ NMR spectrum of 3 . 


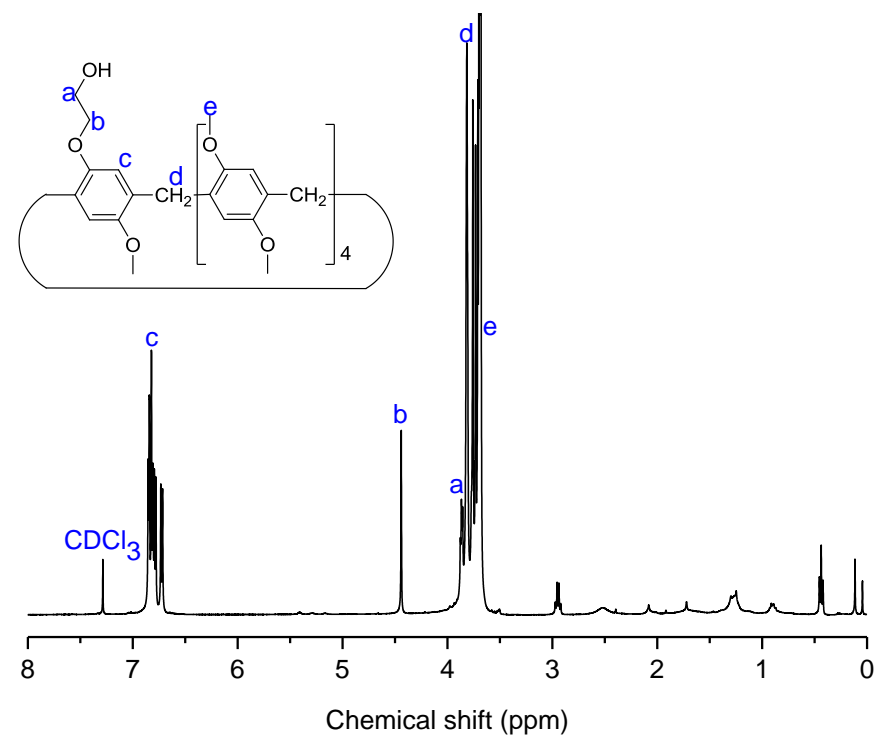

Figure S4. ${ }^{1} \mathrm{H}$ NMR spectrum of 4 .

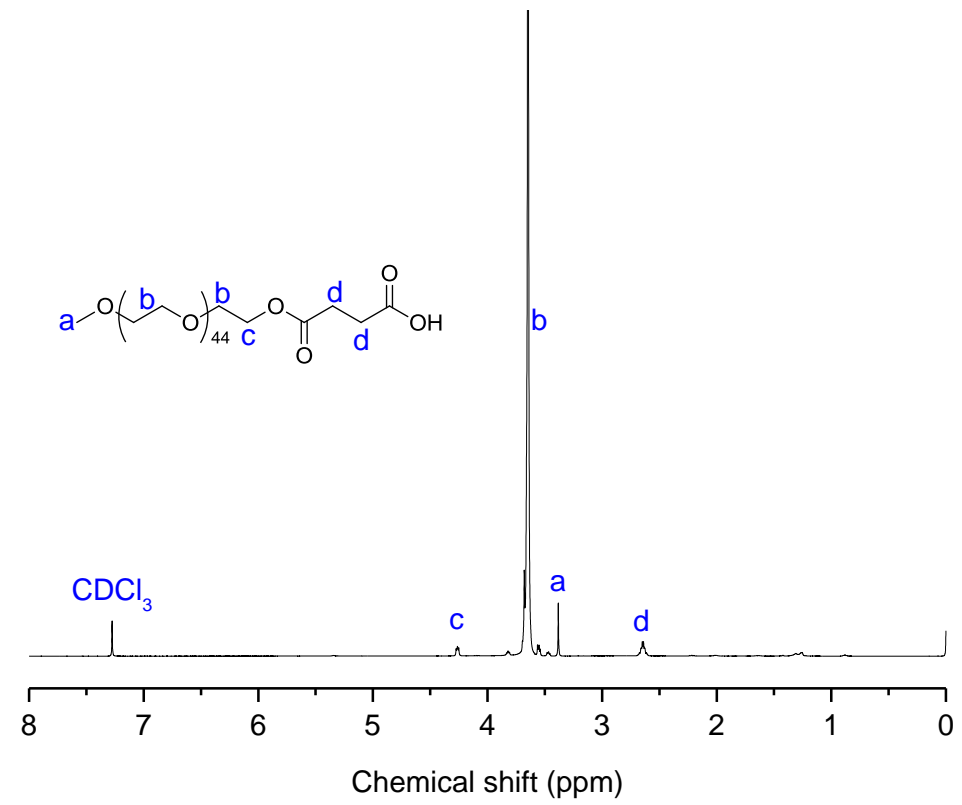

Figure S5. ${ }^{1} \mathrm{H}$ NMR spectrum of 5 . 


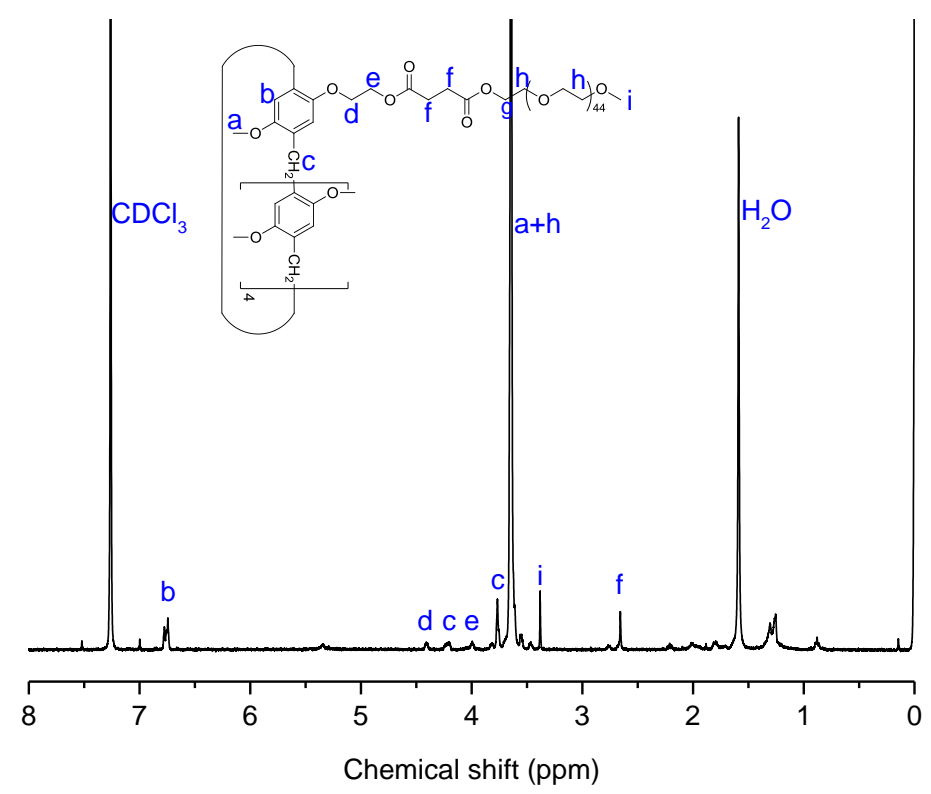

Figure S6. ${ }^{1} \mathrm{H}$ NMR spectrum of PEG-P[5]A.

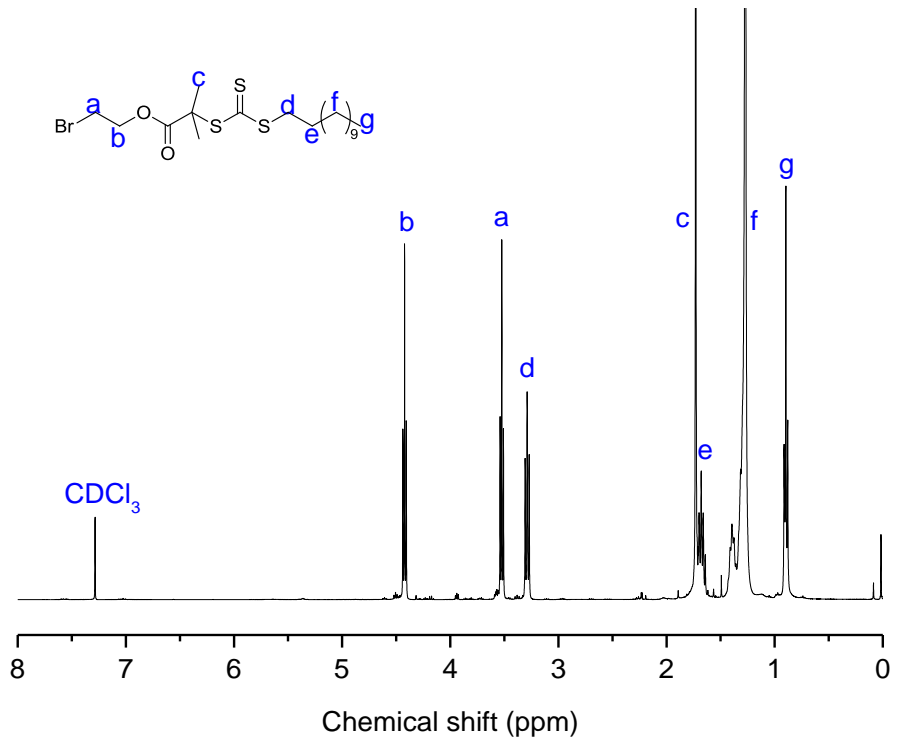

Figure S7. ${ }^{1} \mathrm{H}$ NMR spectrum of 6. 


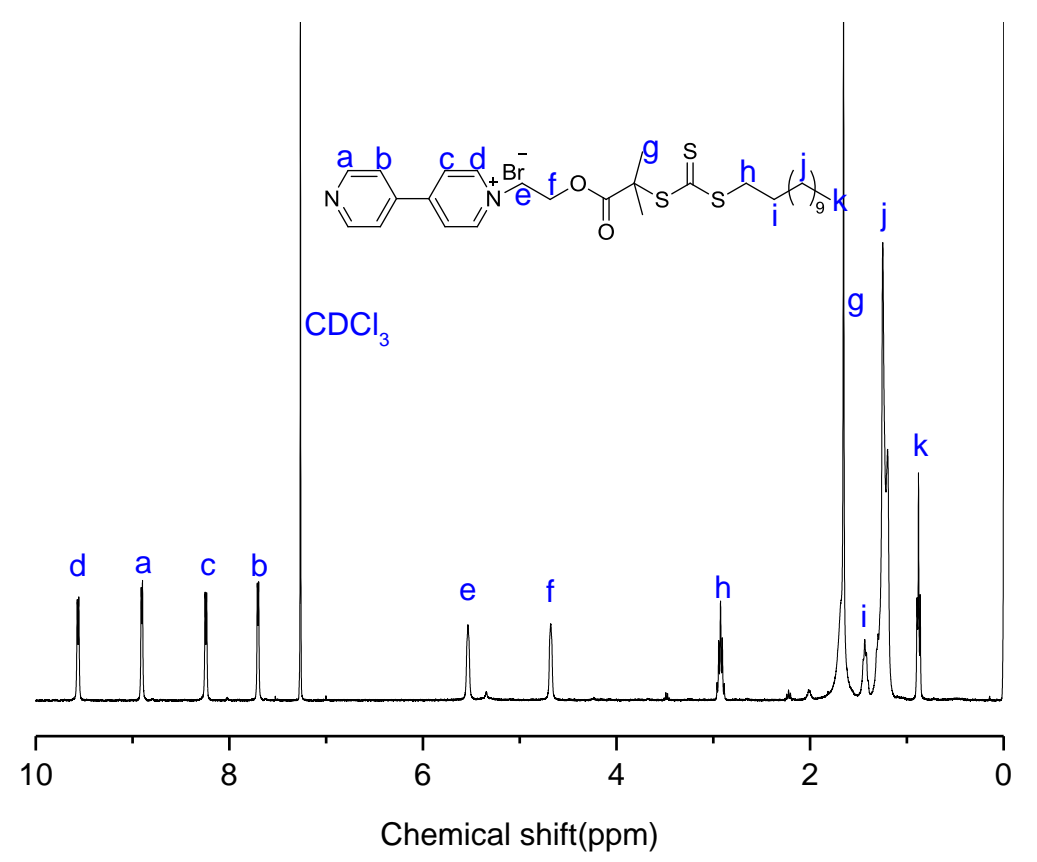

Figure S8. ${ }^{1} \mathrm{H}$ NMR spectrum of 7.

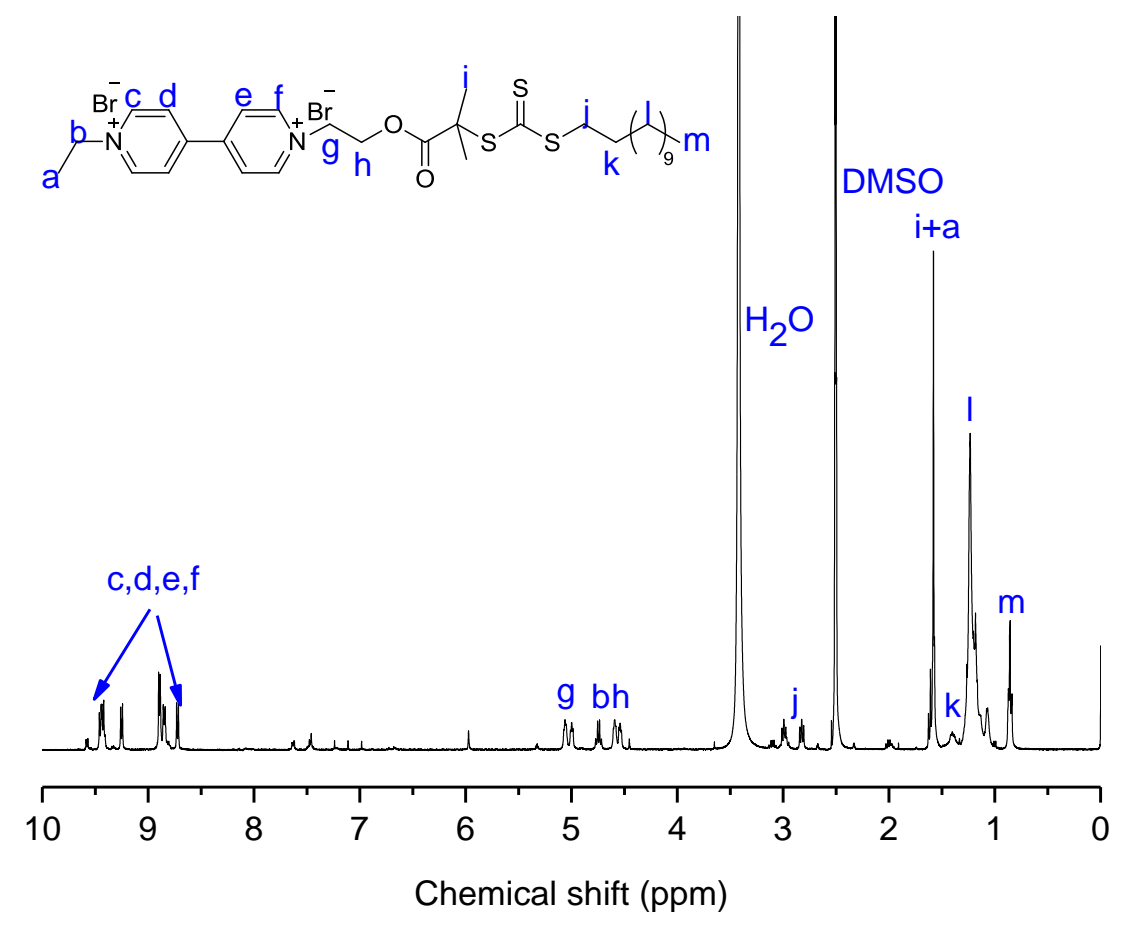

Figure S9. ${ }^{1} \mathrm{H}$ NMR spectrum of 8 . 


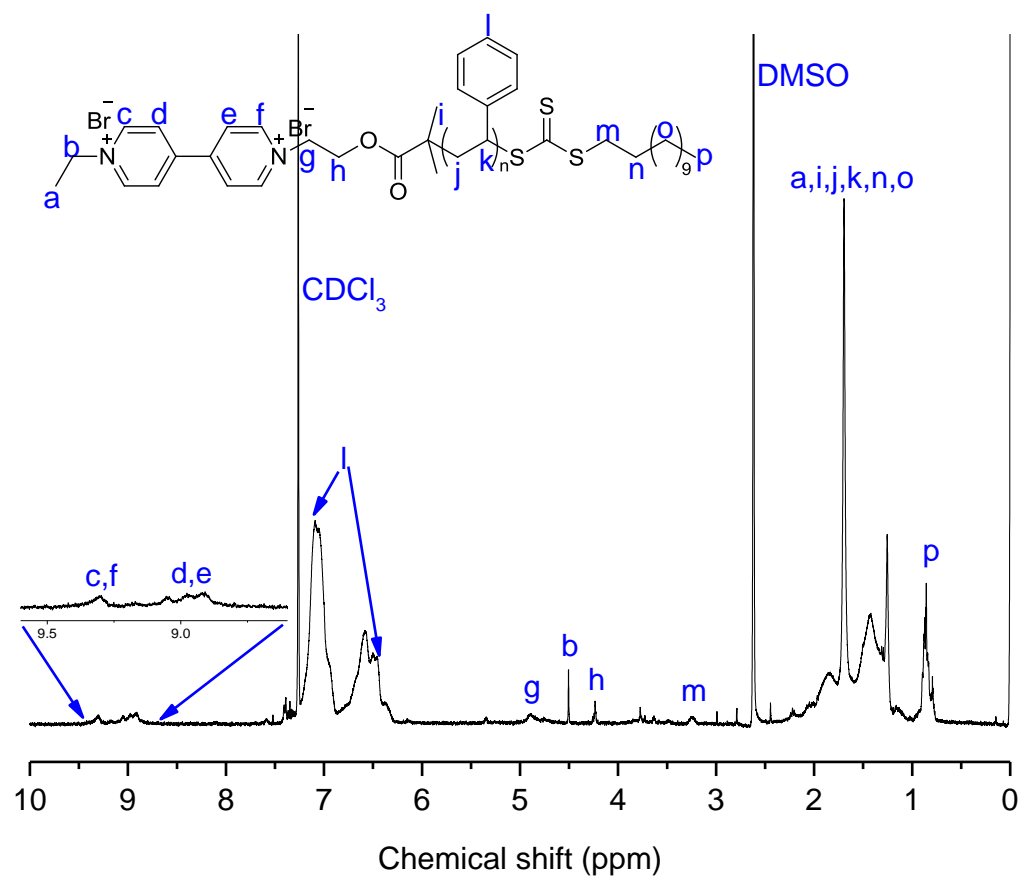

Figure S10. ${ }^{1} \mathrm{H}$ NMR spectrum of $\boldsymbol{P S}-\boldsymbol{E} \boldsymbol{V}$.

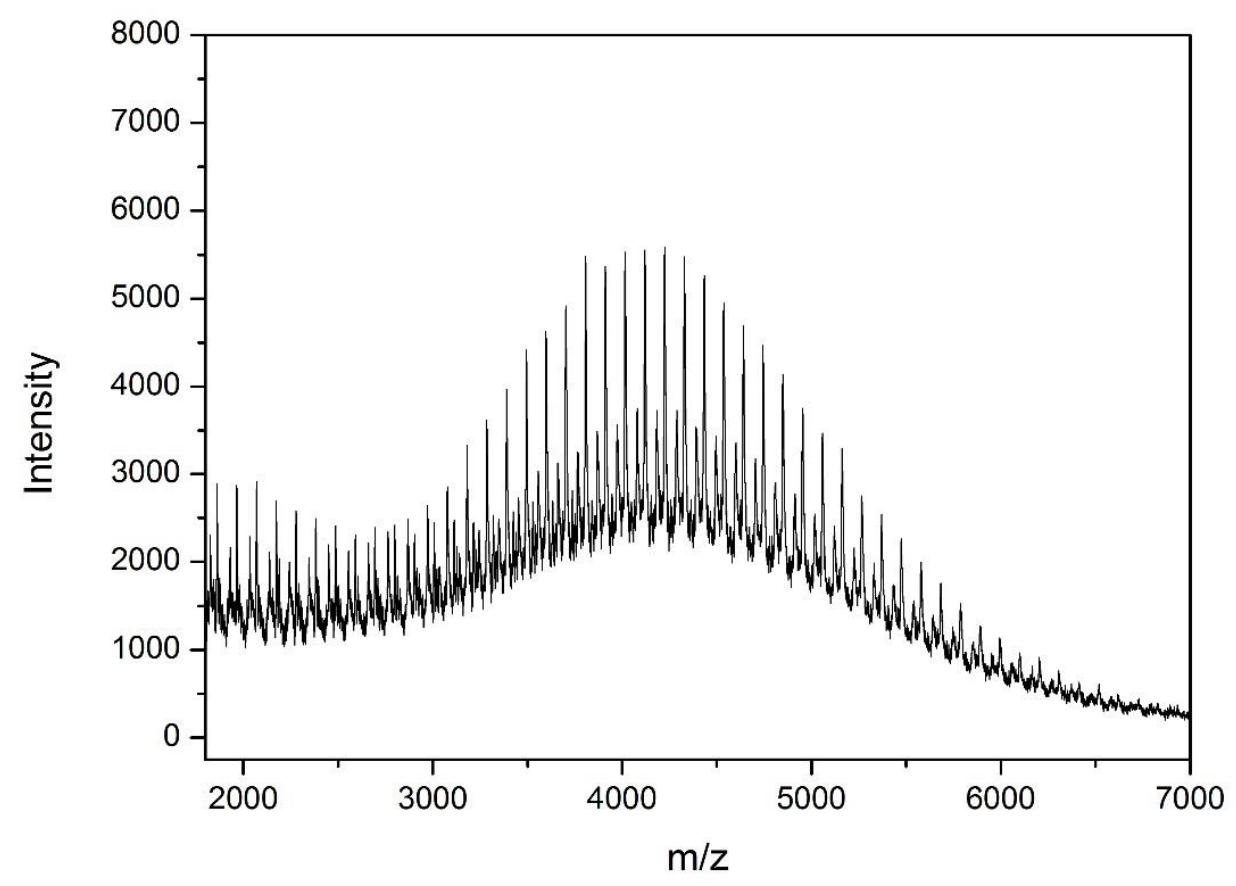

Figure S11. MALDI-TOF-MS spectrum of $\mathbf{P S}_{\mathbf{2 9}}-\mathbf{E V}$. 




Figure S12. Partial ${ }^{1} \mathrm{H}$ NMR spectra $(400 \mathrm{MHz}, 298 \mathrm{~K}$, DMSO): (a) $2.00 \mathrm{mM}$ PEG-P[5]A; (b) $2.00 \mathrm{mM}$ PEG-P[5]A and $\mathbf{P S}_{\mathbf{2 9}}-\mathbf{E V}$; (c) $2.00 \mathrm{mM} \mathrm{PS}_{\mathbf{2 9}}$-EV.

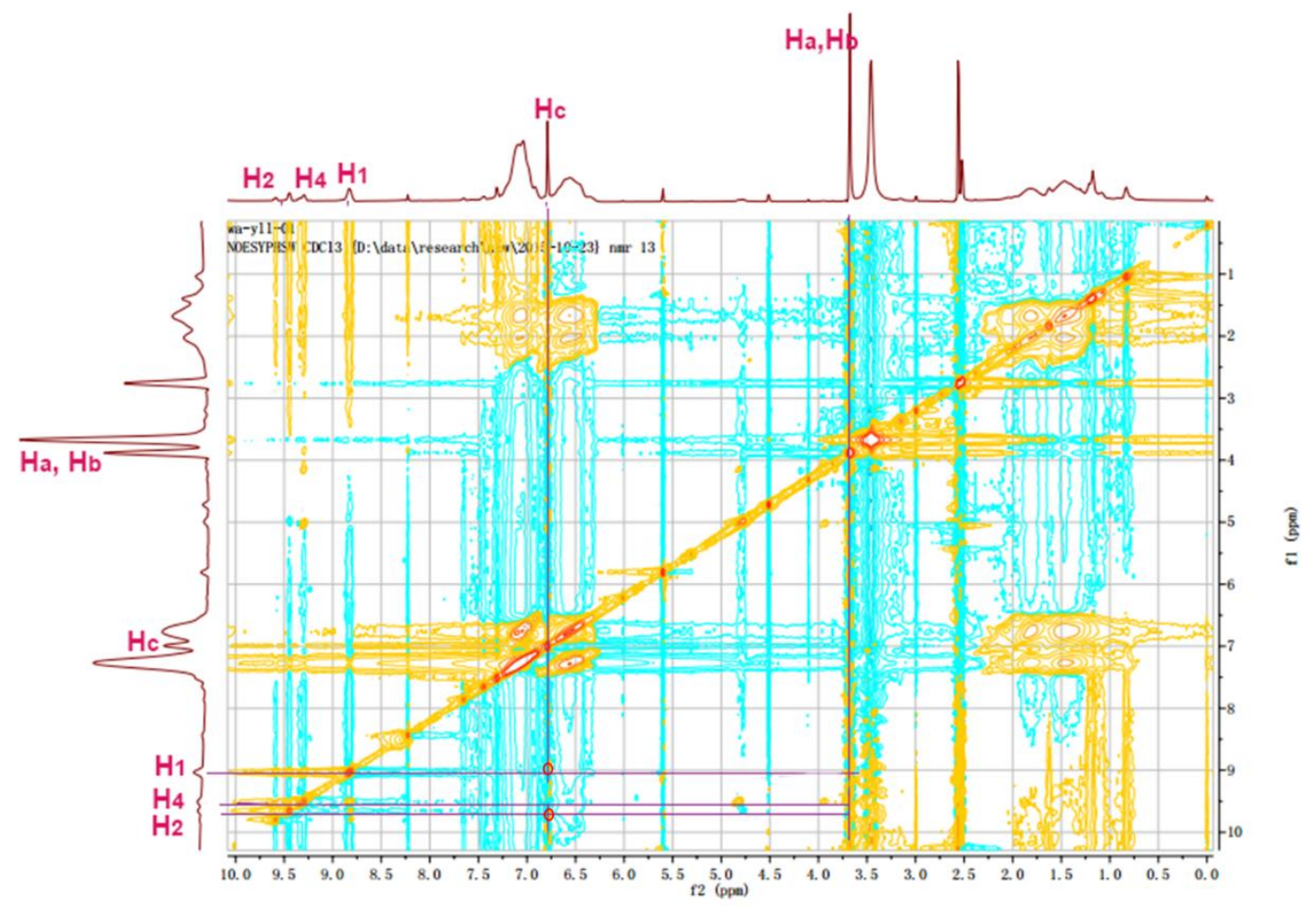

Figure S13. 2D NOESY spectrum of $\mathbf{P}[\mathbf{5}] \mathbf{A} \supset \mathbf{P S}_{\mathbf{2 9}} \mathbf{- E V}\left(400 \mathrm{MHz}, \mathrm{CDCl}_{3}: \mathrm{DMSO}=\right.$ 1:5, $298 \mathrm{~K}),[\mathbf{P}[\mathbf{5}] \mathbf{A}]=20.0 \mathrm{mM},\left[\mathbf{P S}_{29}-\mathbf{E V}\right]=10.0 \mathrm{mM}$. 


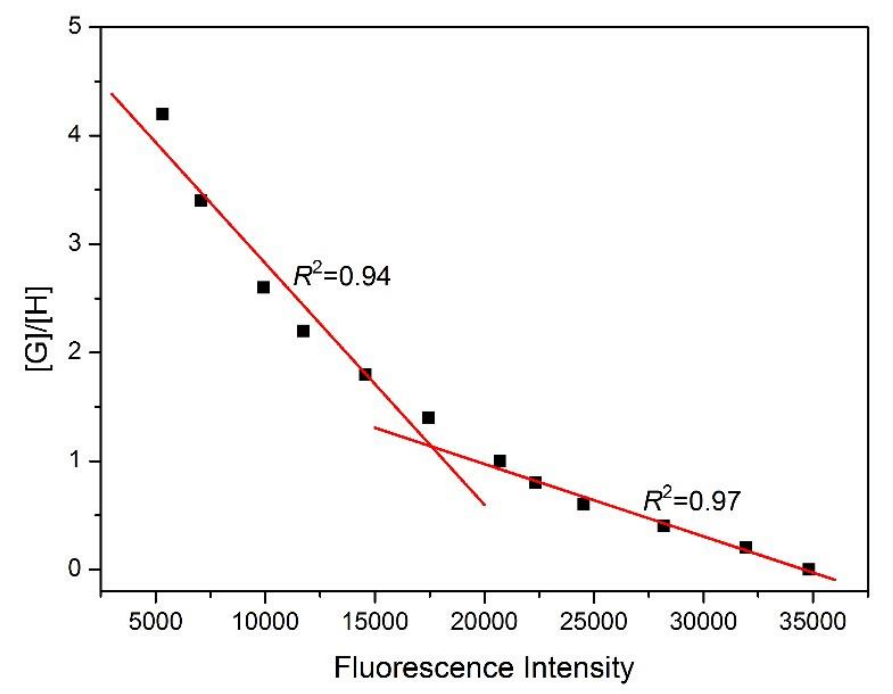

Figure S14. Molar ratio plot for PEG-P[5]A and $\mathbf{P S}_{29}-\mathbf{E V}$, indicating a 1:1 stoichiometry.

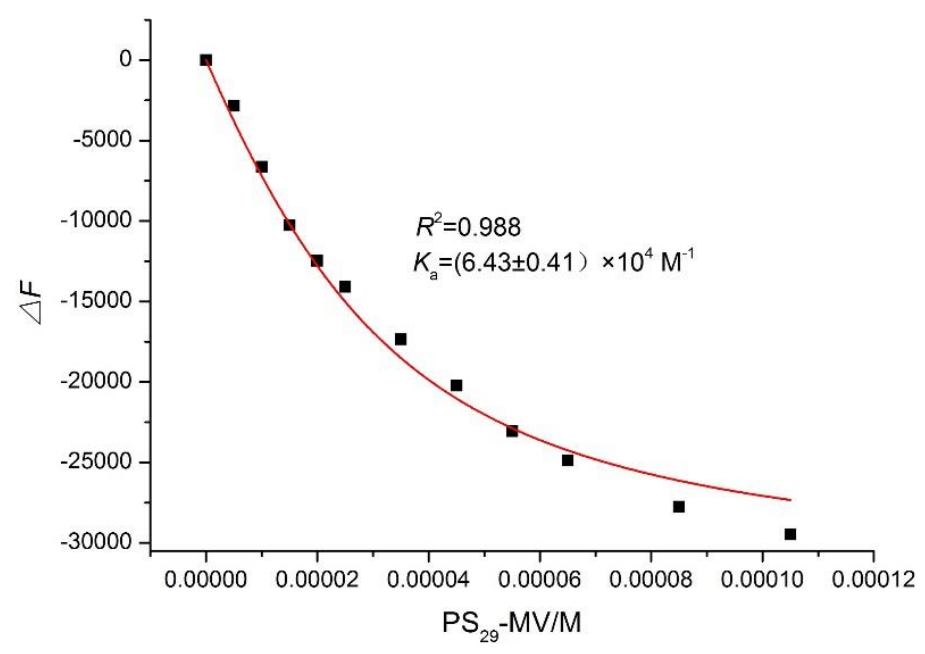

Figure S15. The fluorescence intensity changes upon addition of $\mathbf{P S}_{\mathbf{2 9}}-\mathbf{E V}$. The red solid line was obtained PEG-P[5]A from the non-linear curve-fitting using the above equation. 


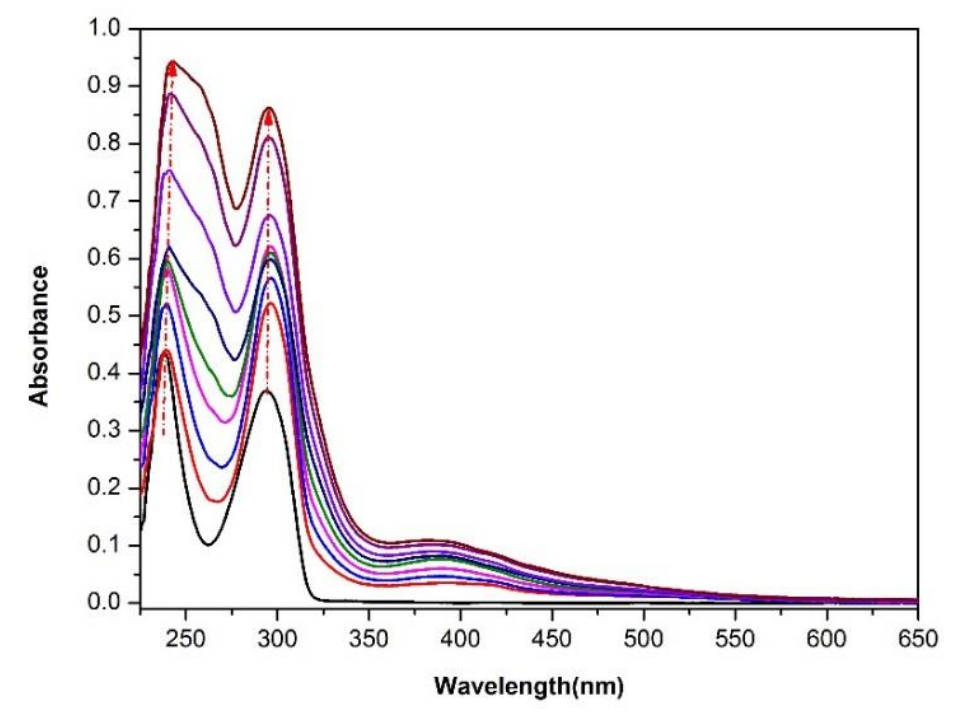

Figure S16. UV-vis absorption spectra of PEG-P[5]A $\left(2.50 \times 10^{-5} \mathrm{M}\right)$ in THF at room temperature with different concentrations of $\mathbf{P S}_{\mathbf{2 9}}$-EV: 0, 1.0, 1.5, 2.0, 2.5, 3.0, 3.5, 4.0, and $4.5 \times 10^{-5} \mathrm{M}$ in THF at room temperature.

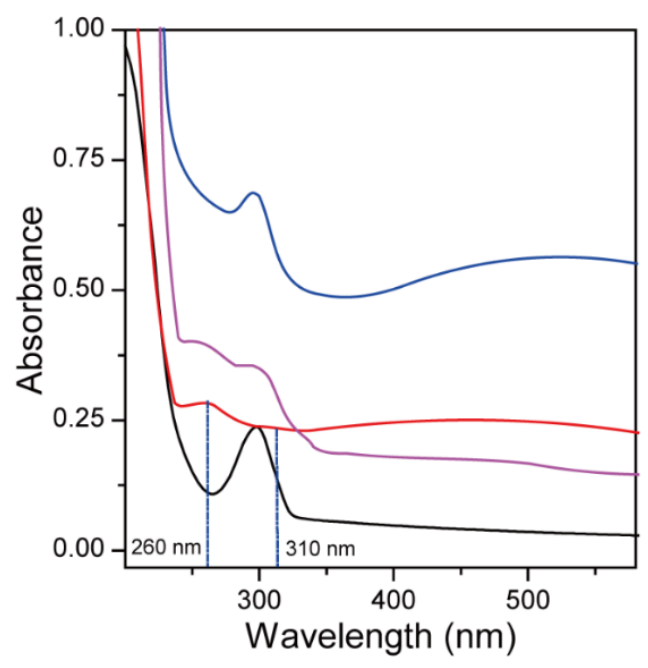

Figure S17. UV-vis absorption spectra in aqueous solution at room temperature of PEG-P[5]A (black solid), $\mathbf{P S}_{\mathbf{2 9}}$-EV (red solid), PEG-P[5]A:PS 2 -EV = 1:1 (blue solid), and PEG-P[5]A:PS 2 -EV = 1:2 (pink solid). 


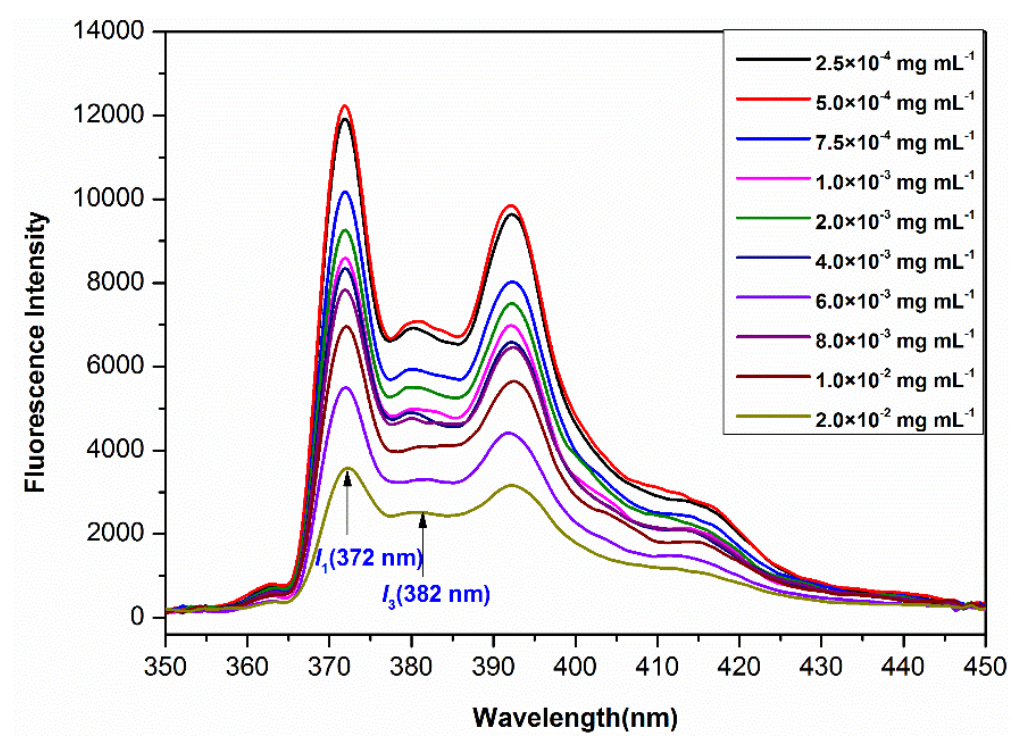

(a)



(b)

Figure S18. (a) Fluorescence spectra of supramolecular diblock copolymers in aqueous solution with pyrene. (b) Plots of fluorescence intensity ratios $\left(I_{3} / I_{1}\right)$ from pyrene emission spectra as a function of the concentration of PEG-P[5]AدPS 2 -EV in aqueous solution at $25^{\circ} \mathrm{C}$. Pyrene concentration was fixed at $6.0 \times 10^{-7} \mathrm{~mol} / \mathrm{L}$. 


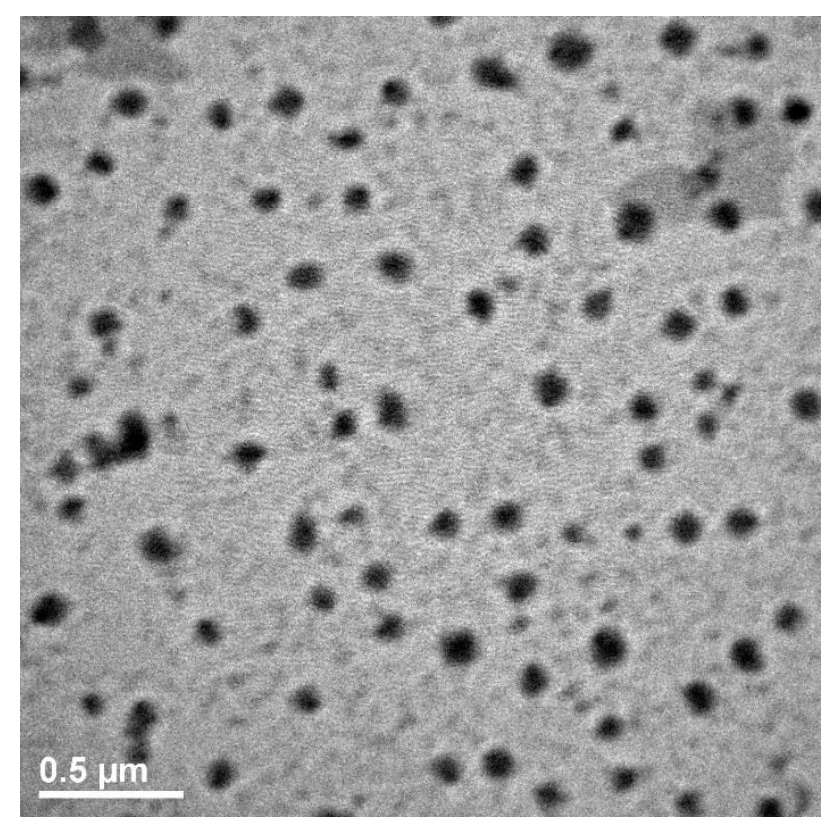

Figure S19. TEM image of PEG-P[5]AدPS 2 -EV (PEG-P[5]A:PS 2 -EV = 1:1) in water with sodium thiosulfate at room temperature.



Figure S20. UV-vis absorption spectra of

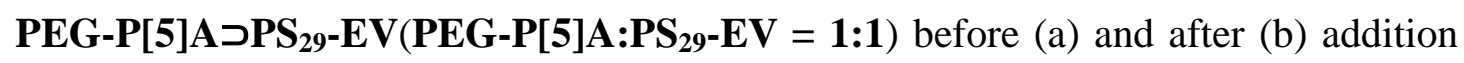
of sodium thiosulfate in aqueous solution at room temperature. 

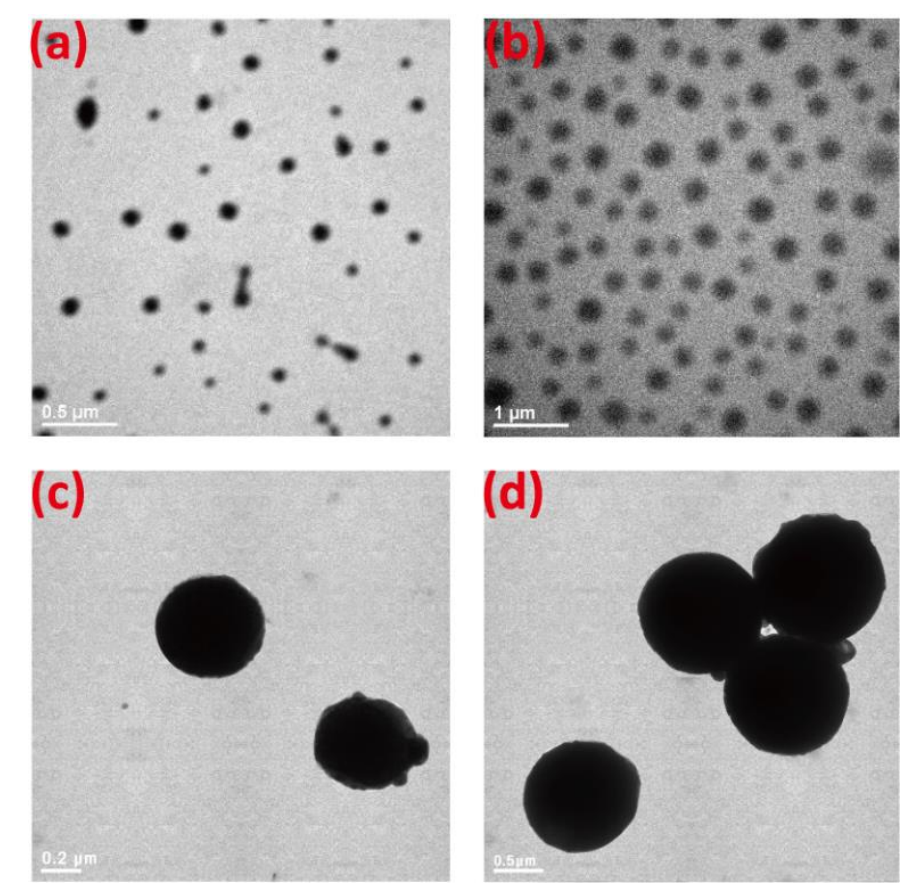

Figure S21. TEM images of (a) PEG-P[5]A, (b) PEG-P[5]A:PS $\mathbf{2 9}_{\mathbf{2}}$-EV = 2:1, (c) PEG-P[5]A: $\mathbf{P S}_{\mathbf{2 9}}-\mathbf{E V}=1: 2$, and (d) $\mathbf{P S}_{\mathbf{2 9}}-\mathbf{E V}$ in aqueous solution.
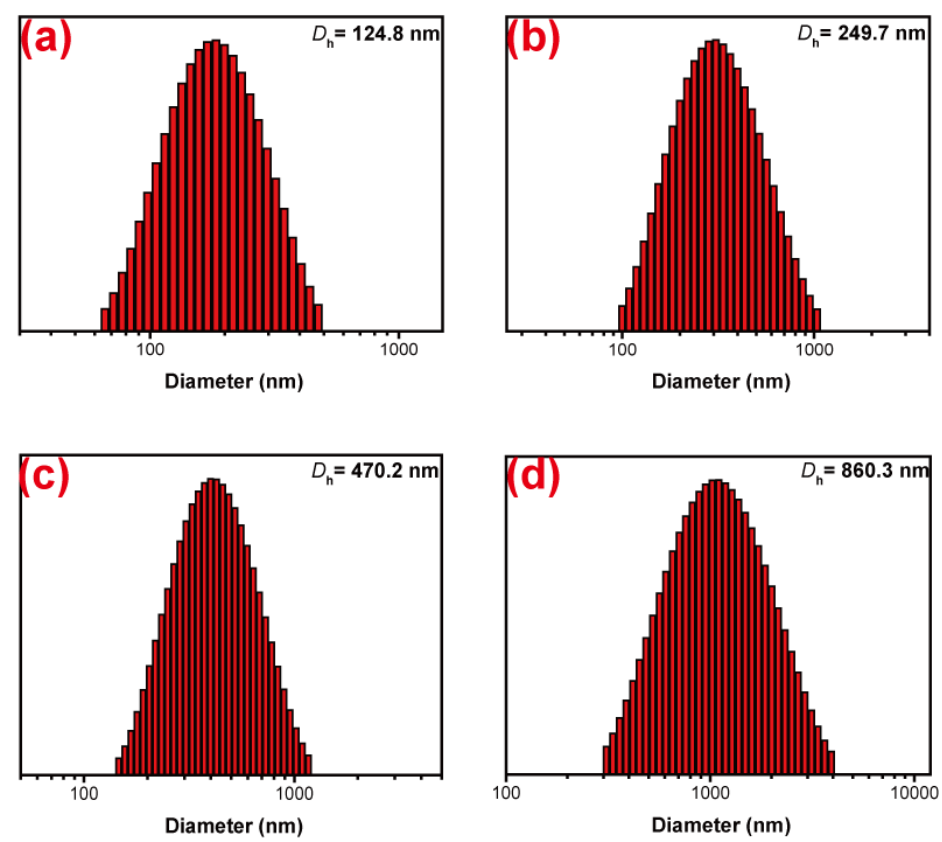

Figure S22. DLS results of (a) PEG-P[5]A, (b) PEG-P[5]A:PS $\mathbf{2 9}-\mathbf{E V}=\mathbf{2 : 1}$, (c) PEG-P[5]A: $\mathbf{P S}_{\mathbf{2 9}}-\mathbf{E V}=1: 2$, and (d) $\mathbf{P S}_{\mathbf{2 9}}-\mathbf{E V}$ in aqueous solution. 

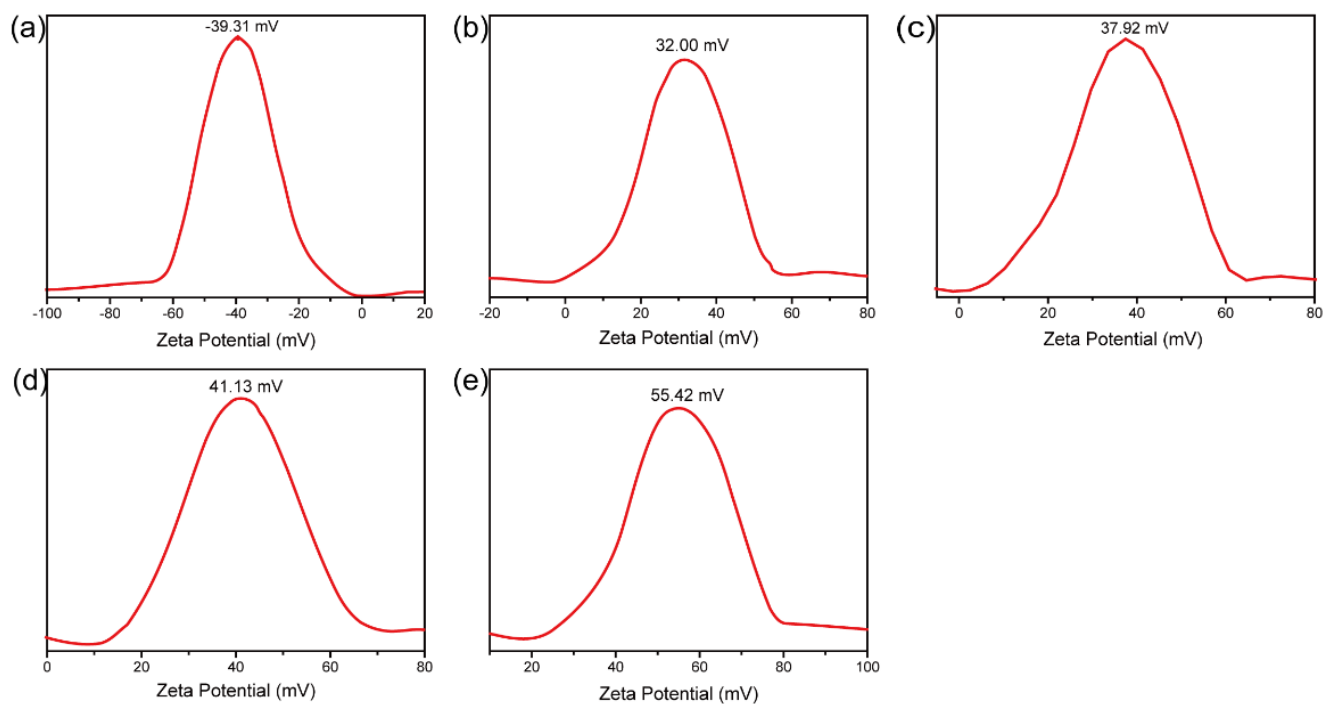

Figure S23. Zeta potential of (a) PEG-P[5]A, (b) PEG-P[5]A:PS $\mathbf{2 9}_{\mathbf{2}} \mathbf{- E V}=\mathbf{2 : 1}$, (c) PEG-P[5]A: $\mathbf{P S}_{29}$-EV = 1:1, (d) PEG-P[5]A: $\mathbf{P S}_{29}$-EV $=1: 2$ and (e) $\mathbf{P S}_{29}$-EV in aqueous solution.

\section{References}

1. Lai, J. T.; Filla, D.; Shea, R. Macromolecules 2002, 35, 6754.

2. Xuan, J.; Han, D.; Xia, H.; Zhao, Y. Langmuir 2013, 30, 410.

3. Ackermann, T. Berichte der Bunsengesellschaft für physikalische Chemie 1987, 91, 1398.

4. Ashton, P. R.; Ballardini, R.; Balzani, V.; Bělohradský, M.; Gandolfi, M. T.; Philp, D.; Prodi, L.; Raymo, F. M.; Reddington, M. V.; Spencer, N.; Stoddart, J. F.; Venturi, M.; Williams, D. J. Journal of the American Chemical Society 1996, 118, 4931.

5. Zhang, J.; Huang, F.; Li, N.; Wang, H.; Gibson, H. W.; Gantzel, P.; Rheingold, A. L. The Journal of Organic Chemistry 2007, 72, 8935.

6. Wang, K.; Guo, D.-S.; Wang, X.; Liu, Y. ACS Nano 2011, 5, 2880. 